\title{
Evaluation of blood sugar lowering effect of airy organs extract of Cupressus sempervirens L. on streptozocin induced diabetic mice
}

\author{
Shaki $\mathbf{F}^{\mathbf{1}}$, Habibi $\mathbf{E}^{2}$, Parandavaji $\mathbf{M}^{3}$, Ataee $\mathbf{R}^{4}$ \\ 1. Assistant Professor of Toxicology, Pharmaceutical Sciences Research center, Hemoglubionopathy Instittue, Mazandaran \\ University of Medical Sciences, Sari, Iran. \\ 2. Assistant Professor of Pharmacognosy, Pharmaceutical Sciences Research Center, Hemoglubionopathy Instittue, \\ Mazandaran University of Medical Sciences, Sari, Iran. \\ 3. Student of Pharmacy, Pharmacy Department, Phamacy School, Mazandaran University of Medical Sciences, Sari, Iran. \\ 4. Assistant Professor of Pharmacology, Thalassemia Research Center, Pharmaceutical Sciences Research Center \\ Hemoglubionopathy Instittue, Mazandaran University of Medical Sciences, Sari, Iran (Corresponding Author), Tel: +98-11 \\ 33543083, Email: raminataee1349@gmail.com
}

\begin{abstract}
Background and Aim: Cupressus extract has been considered as antioxidant and free radical scavenger. In this study we evaluated the effect of hydroalcoholic extract of Cupressus sempervirens L. on blood sugar, weight and also oxidative stress parameters in experimental diabetic model of mice.

Materials and Methods: 48 male mice of albino race were made diabetic with a single dose of streptozocin (200mg./kg IP injection) for every mouse, and divided into 6 groups of 8 including: positive control(diabetic),negative control (DMSO $10 \%$ in normal saline, metformin(100mg.kg),three test groups(which received 50,100,200 mg.kg of the extract respectively by gavage for three weeks). After the treatment period, blood glucose level, weight and oxidative stress parameters such as MDA,GSH and mitochondria proliferation were measured. Using SPSS software 21, data were analyzed by ANOVA and Mann Whitney statistical analysis.

Results: Our results showed that use of hydroalcohlolic extract of Cupressus sempervirens L. reduced blood sugar in a dose dependent way $(\mathrm{P}<0.01)$ but there was no significant change in the weights of the mice $(\mathrm{P}>0.05)$ and we found decreased oxidative stress parameters and improved hepatic mitochondrial proliferation $(\mathrm{P}<0.01)$.

Conclusion: According to the results of this study we can conclude that Cupressus sempervirens L. extract can be effective in reduction of blood glucose and prevention of diabetic induced damage to the liver tissue.
\end{abstract}

Keywords: Cupressus sempervirens L, Diabetes, Oxidative stress, Streptozocin, Metformin Received: Nov 4, 2018

Accepted: March 6, 2019

How to cite the article: Shaki F, Habibi E, Parandavaji M, Ataee R. Evaluation of blood sugar lowering effect of airy organs extract of Cupressus sempervirens L. on streptozocin induced diabetic mice. SJKU 2019;24(2):52-65. 


\title{
بررسى اثر كاهندكى قند خون عصاره اندام هوايى سرو زربين
}

بر موش ديابتى شده توسط استريتوزوسين (Cupressus Sempervirens)

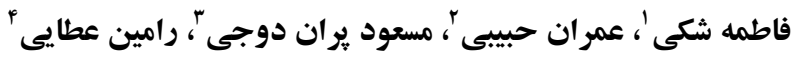

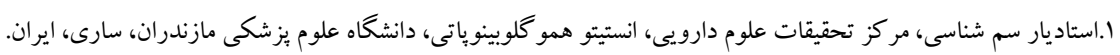

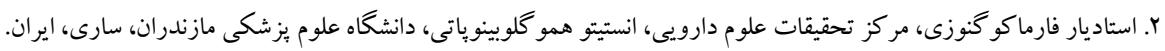

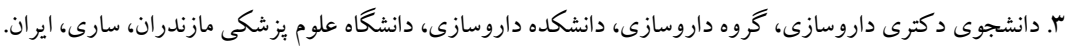

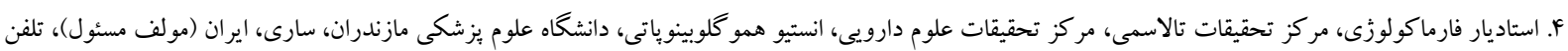 \\ ثابت: raminataee1349@gmail.com
}

\section{جָكيله}

زمينه و هدف: عصاره گياه سرو بهعنوان يكك آنتى اكسيدانت قوى و جاروب كننده راديكالهاى آزاد مطرح است. در اين مطالعه

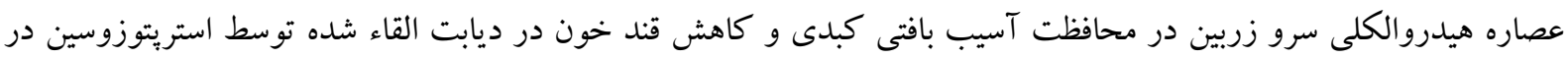

$$
\text { موش سورى مورد ارزيابى قرار گرفت. }
$$

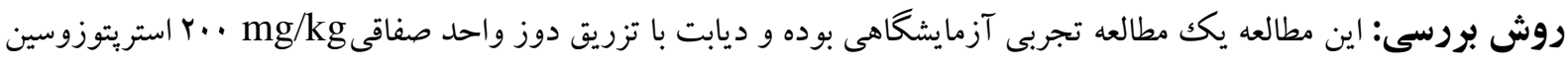

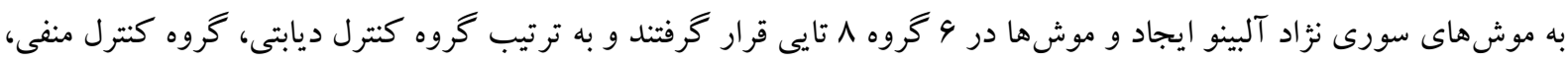

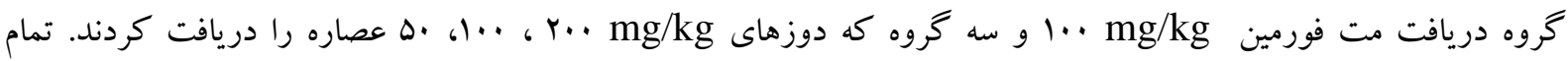

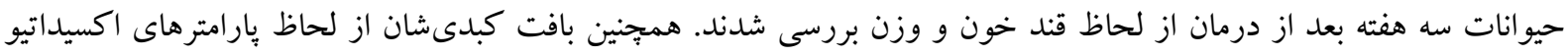

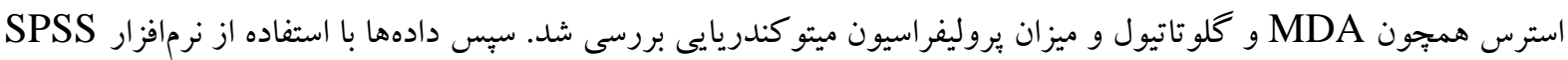

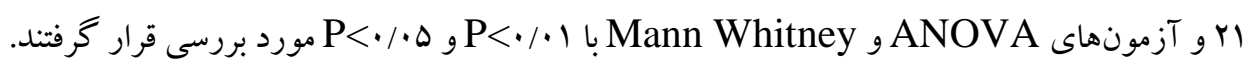

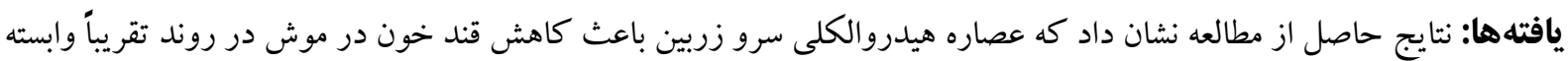

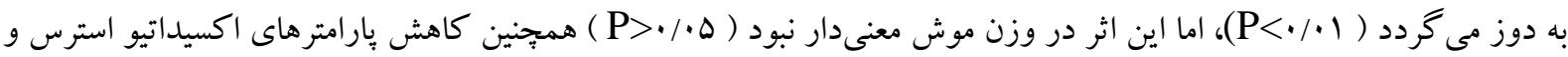

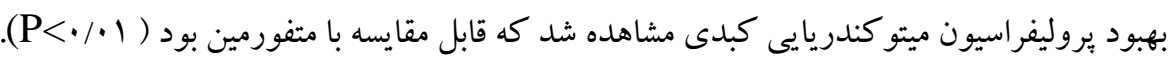
نتيجه كيرى: يافتهاى ما نشان مىدهد كه عصاره سرو علاوه بر كاهش قند خون باعث اثرات محافظتى بر آسيبهاى بافت كبدى ناشى از ديابت مى كردد. كليد وازه ها: گياه سرو زربين، ديابت، استرس اكسيداتيو، استريتوزوسين، متفورمين وصول مقاله :QV/N/Ir اصلاحيه نهايى:QV/IY/D بذيرش:QV/IY/ID 
هاى سويراكسيد، هيدروزن : يراكسيد و راديكال هاى هيدروكسيل توليد مىشود كه با توجه به مراحل احيا، به

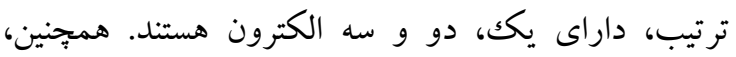

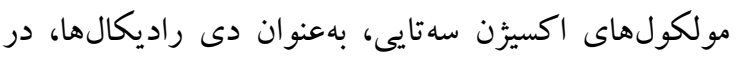

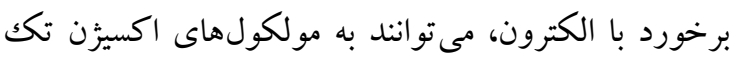

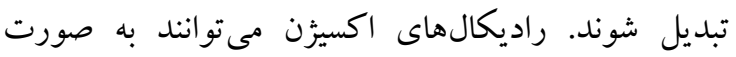

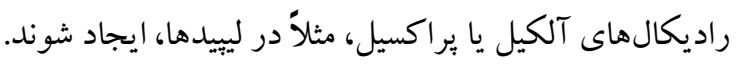

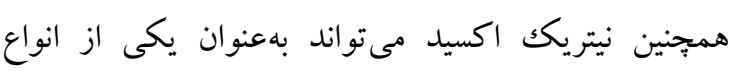
راديكالهاى كازى در شرايط بيولوزيكك توليد شوده

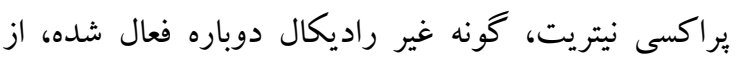

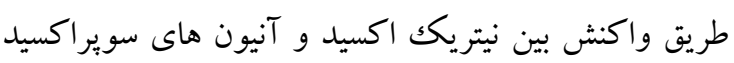
ايجاد مىشود. نيمه عمر راديكالهاى مختلف اكسيزن با يكديخر تفاود زيادى دارند و در نتيجه نياز به مكانيسمهاى دفاعى متفاوتى دئى

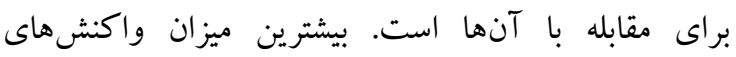
انجامشده با مولكولهاى هدف در راديكالهاى هيدرو كسيل

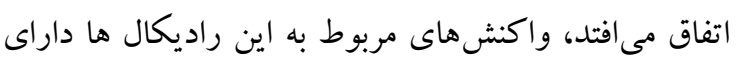
محدوديت انتشار است و اين بدان مفهوم است كه واكنشها مربه

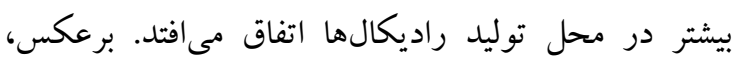

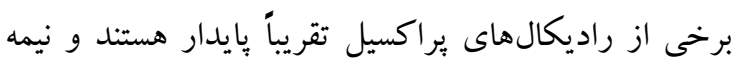

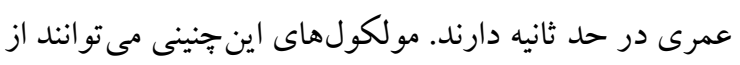

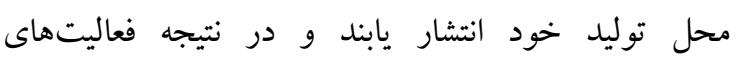

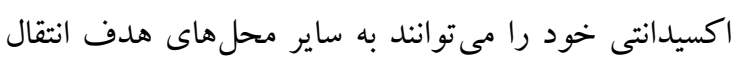

دهند (9) (9).

آنتى اكسيدانت هاى مختلف آلفا-لييوئيك اسيد، تورين، استيل-ال-كارنى تين، M40403 و بتاكاروتن اثرات خوبى النى

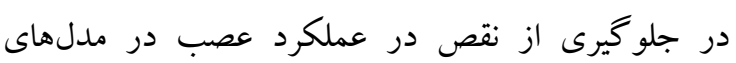
نوروباتى ديابتى از خود نشان دادند (N)، V).

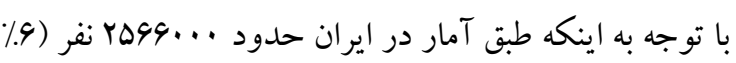
جمعيت) به ديابت مبتلا هستند و تخمين زده مى شود كه مشابه كشورهاى در حال توسعه اين آمار در سال ه广.r.r به

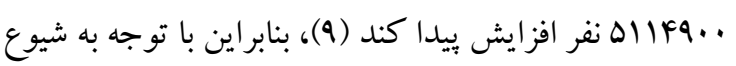

ديابت مليتوس يكى از مهمترين مشكلات سلامت انسانها

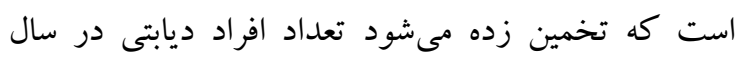

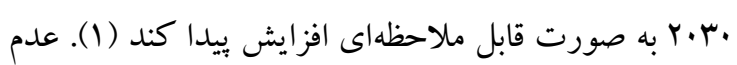

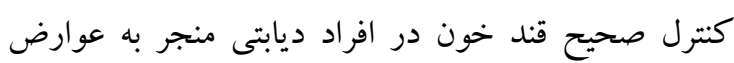
شديدى مثل نوروياتى، رتينوياتى و نفروياتى مىشود. نوروباتى ديابتى به صورت شرايط مختلفى از درد مانى مانند افزايش حساسيت به درد (hyperalgesia) ديده مي شود انو دورد

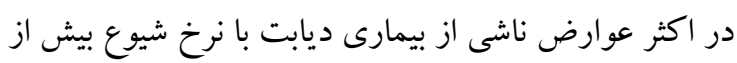
• له درصد گزارش شده است (Y). نقص در هدايت عصب حسى و حركتى و ديخر تظاهرات

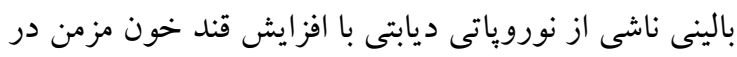

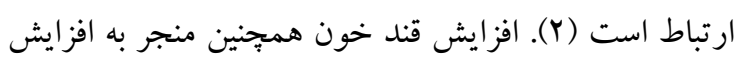
استرس اكسيداتيو (از طريق افزايش توليد راديكال هاى آزاد يا نقص در سيستم دفاع آنتى اكسيدانت)، بروز ايسكمى/هاييو كسى در عصب و نقص در فاكتورهاى رشد

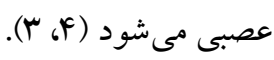
جندين مطالعه بيشنهاد داده است كه استرس اكسيداتيو ممكن است يكى از مهمترين مسيرهاى ايجاد نوروياتى

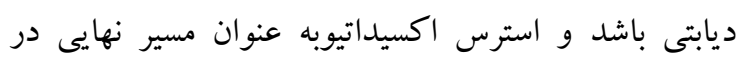
ايجاد نوروياتى ديابتى شناخته شده است و و تداخلات آندات

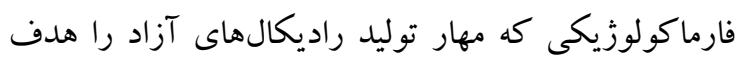

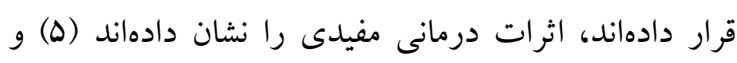

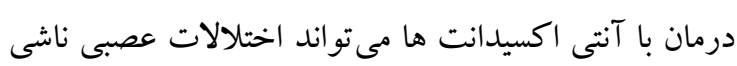
از افزايش قند خون جلو گيرى كند (9) (9). عدم تعادل بين عوامل اكسيدانت و آنتى اكسيدانت، به طور

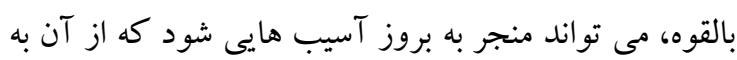

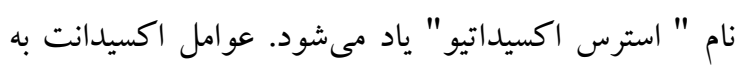

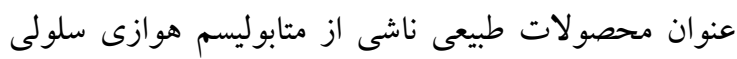

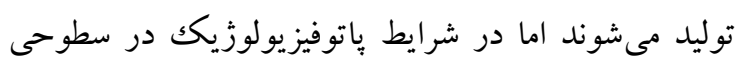

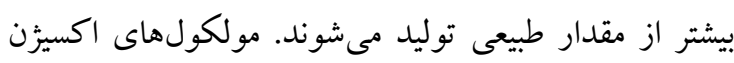
مى تواند به آب احيا شوند. در مراحل ميانى اين احيا، آنيون 
سـاعت روشـنايى و rا سـاعت تـاريكى در اتـاق حيوانـات

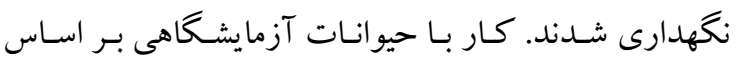

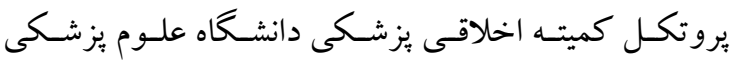
مازندران كد طرح و اخلاق

اندام هوايى سرو (كل و ميوه) از اطراف سارى (كيلومتر هـ

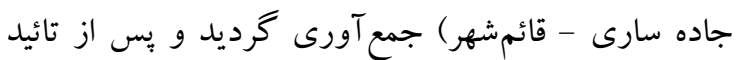

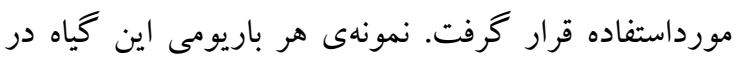

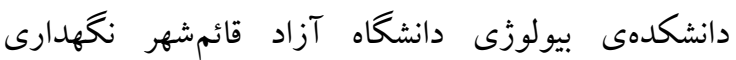
مىشود. بخش هوايى گياه در هواى آزاد و در سايهخشك

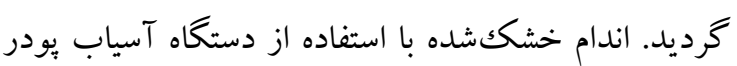
شده تا به ذرات با قطر حدود ب تا ب ميلىمتر تبديل شدند.

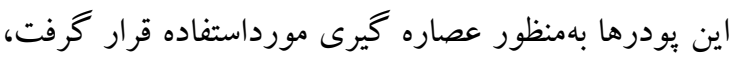

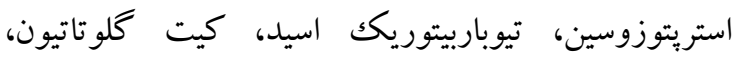
dimethylthiazol-2-yl]-2,diphenyl-،Tris-Hcl MTT)((tetrazolium bromide) (آلمان)، مت فورمين از شر كت راموفارمين (ايران)، مانيتول،

ساكارز، ان -بوتانول، ( EDTA Hcl ((Ethylenediaminetetraacetic acid) MERK از شركت (DMSO,Dimethyl sufoxide) (آلمان) و اتانول از شركت الكل طب اراكك تهيه شد.

\section{عصاره كيرى از كياه سرو}

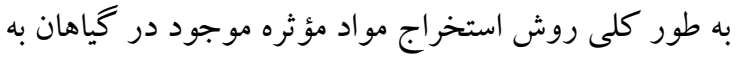

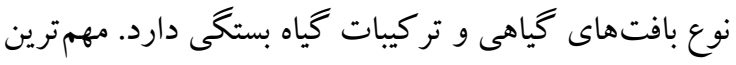

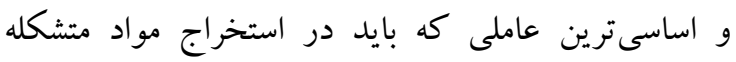

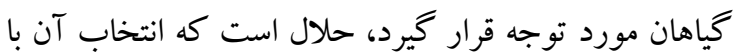
توجه به قسمتهاى مختلف گياه سرو و نيز مواد متشكله آن

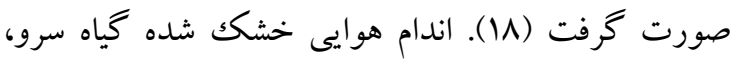
بِ از خرد نمودن به صورت ذرات ب تا ب ميلىمترى

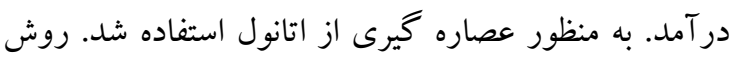

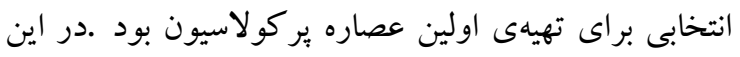

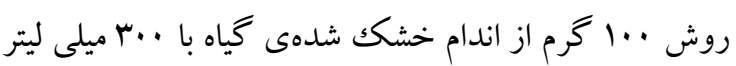

بالاى اين بيمارى و بحث اقتصادى و اجتماعى ناشى از عوارض بيمارى، درمان مؤثر با عوارض كم ضرورى به نظر مىرسد. در سالهاى اخير بحث استفاده از خياهان دارويى در درمان بيمارىهاى مختلف از جمله ديابت مطرح شده

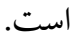

كياه سرو زربين با نام علمى ( cupres (cupres سرو زبين (sussempervirens (pinophyt) دسته مخروطيان (sussempervirens) ردهى نازويان (pinopsid) راستهى كاجيان (pinales) تيرهى سروها (cupressacea) رده سروناز (cupressus) است؛ كه بسيارى از خواص آن از قبيل محافظ از مواد

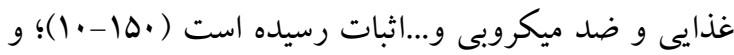

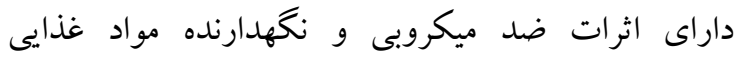
و...است. مطالعات مختلف اثرات ضد ميكروبى، آنتى اكسيدانتى، آنتى كانسرى و محافظت كبدى اين خياه را

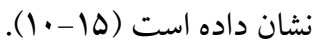
همجِنين بسيارى از مطالعات نشان داد كه كاهش استرس

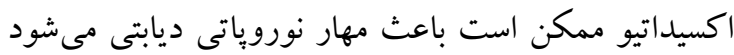

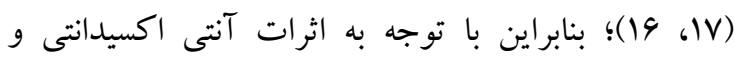

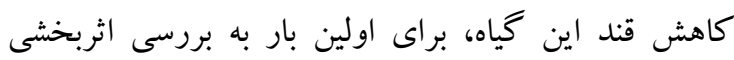

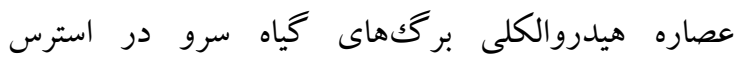
اكسيداتيو ناشى از ديابت ايجاد شده توسط استريتوزوسين و تأثير آن در روند درمان به عنوان داروى كمكى داني در كنار داروهاى استاندارد درمان ديابت مثل متفورمين مى بردازيم.

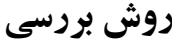

حيوانات

موش هاى سورى با نزاد Albino نر به وزن .ب-هو گرم از

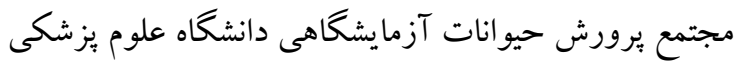
مازندران تهيه و در شرايط مناسب رطوبت و دما (دماى YV

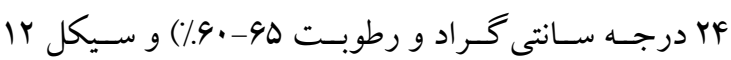


(بهصورت محلول در DMSO . DM به مدت r هفته دريافت داشتند. گروه • ·-1 موش ديابتى به مدت ب هفته داروى مت فورمين را در دوز 100mg/kg به مدت 9 هفته در يافت كردند. تمام حيوانات قبل از القاء ديابت و نيز دو هفته بعد از القاء و در هفتهاى ب و \& و و 4 بعد از دادن عصاره، از لحاظ قند خون و وزن و ميزان بيوماركرهاى استرس اكسيداتيو بافت كبدى بررسى گرديدند (كلوتايتون،

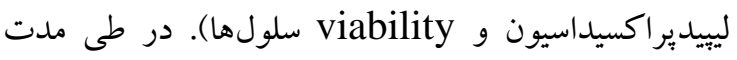
تحقيق حيوانات در شرايط استاندارد آزمايشگاهى (دماى r r

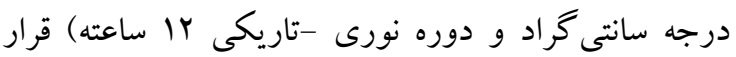

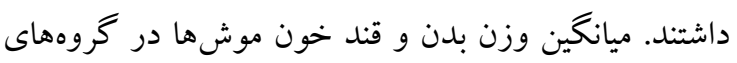

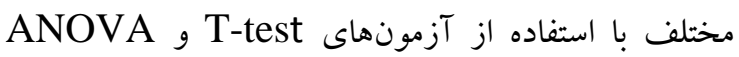
يككطرفه و متعاقب آن نيومن كولز مورد تجزيه و تحليل قرار خواهند گرفت. بِ از سبرى شدن دورهى درمان، حيوانات با گيوتين كشته

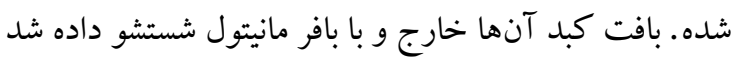

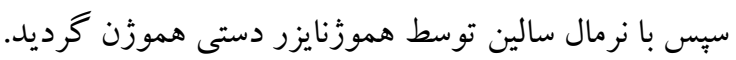

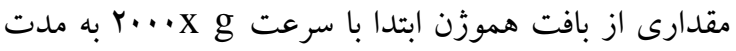

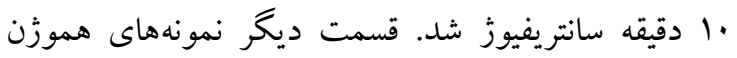

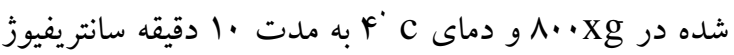

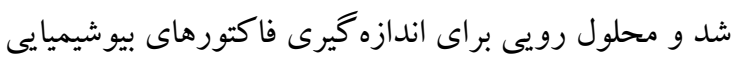
و استرس اكسيداتيو استفاده شد (Y)، •r).

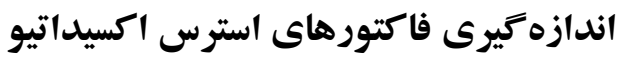
اندازهكيرى ليبيديراكسيداسيون

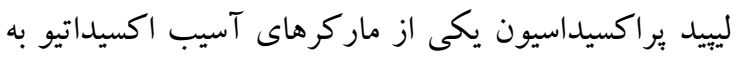

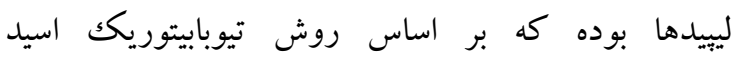
اندازه گيرى مىشود بدين ترتيب كه به

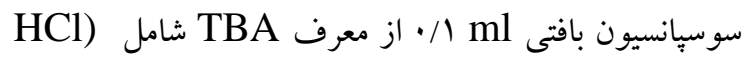
ه/• نرمال TCA خوبى مخلوط و در حمام آب گرم به مدت .بr دقيقه انكوبه

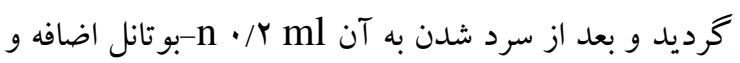

اتانول مخلوط شد؛ مجموعه به مدت YF ساعت در دماى محيط رها شد. پس از FF ساعت مجموعه صاف شده و

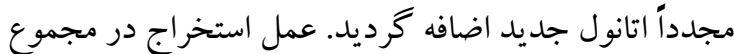
ץ بار تكرار شد. حلالها به كمك دستكاه روتارى در خلأ (در دماى حدود ها درجه) تبخير شده و سبس مجموعه به كمكك فريز دراير خشك گرديد. بدين ترتيب عصاره اتانولى با بازده ه/ه \% به دست آمد (19).

روش القاء ديابت

دو هفته پֶسازاينكه موشهاى سورىها با محيط آشنا شدند، ديابت با تزريق استريتوزوسين در موشهاى سورى ايجاد

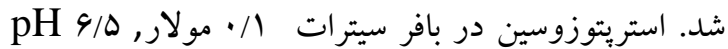
حل شده و با دوز r... mg/kg به روش داخل صفاقى

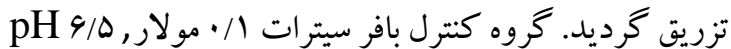

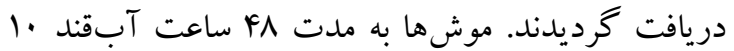

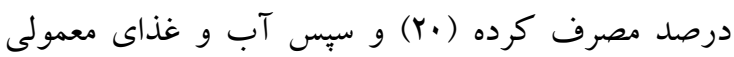
دريافت مىدارند. قند خون قبل از آزمايش و يكك هفته پِ

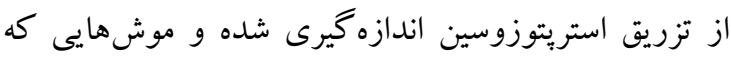

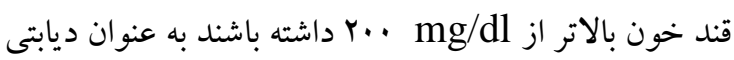

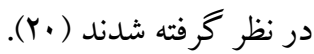
كروههاى مورد آزمايش

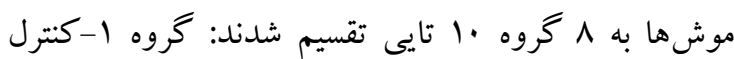

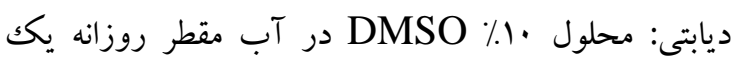

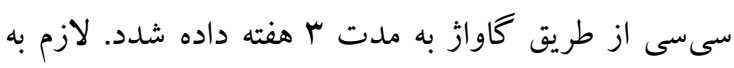
توضيح است كه مدت بررسى سه هفتهاى موشهاى درئ ديابتى

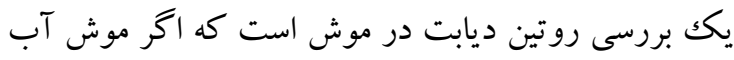

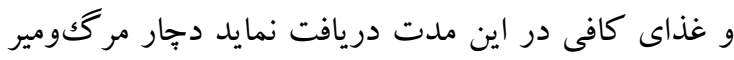

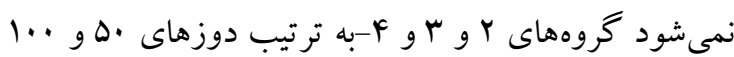

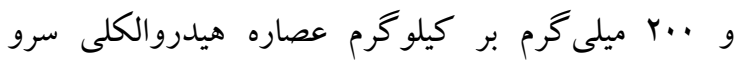

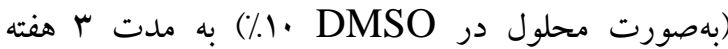

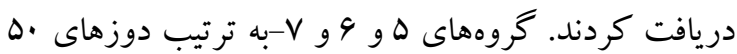

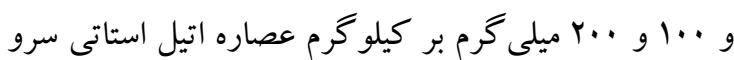


بلورهاى بنفش رنخك فورمازان، ا ميلىليتر DMSO اضافه كرده و با شدت به هم مىزنيم تا حل شوند. ..' ميكرو ليتر

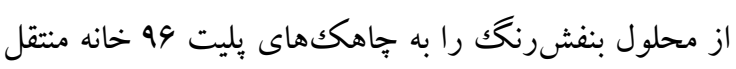

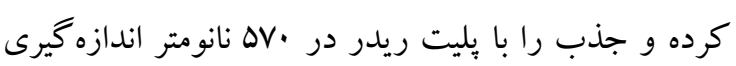

بر اساس مطالعات موجود و از طريق فرمول حجم نمونه محاسبه شد. در نهايت نتايج برحسب ميانخين土 انحراف

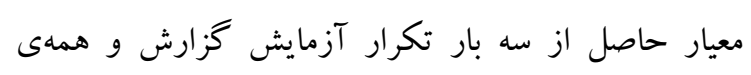

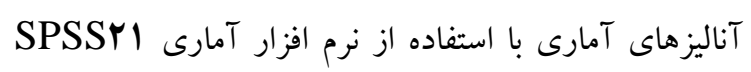

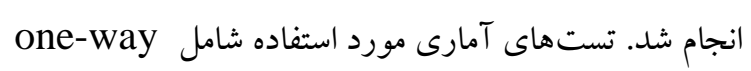
ANOVA test

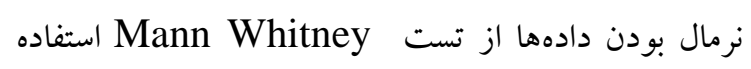

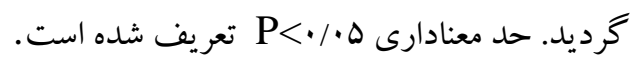

يافته ها تأثير كياه سرو زربين بر روى ميزان قند خون موشهاى نرمال و ديابتى شده

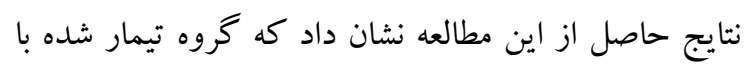

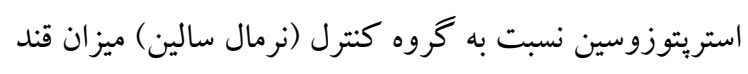

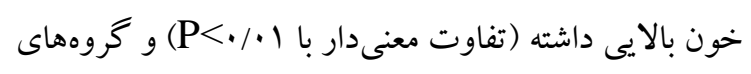
تيمار شده با عصاره و متفورمين نسبت به خروه بالايى ديابتى

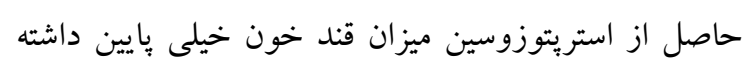

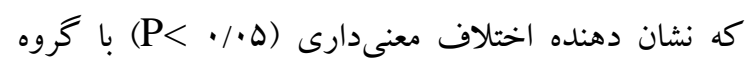

$$
\text { استريتوزوسين است (نمودار ()). }
$$

خوب تكان داده شد سبس در 9g.... سانتريفوز شد لايه n - بوتانل براى سنجش در طول موج

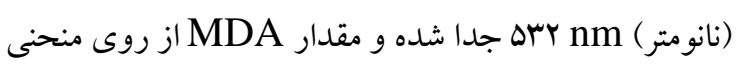

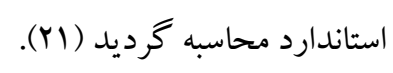

\section{اندازه كيرى سطوح كلوتاتيون}

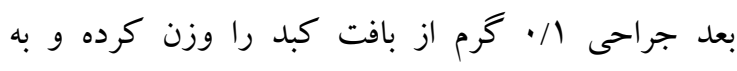

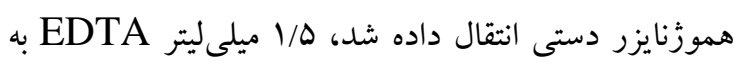

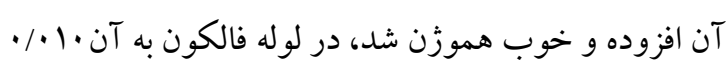

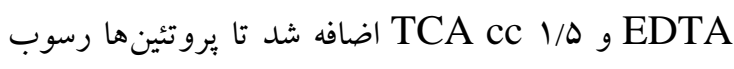
كنند، سبس به مدت پِانزده دقيقه در دور

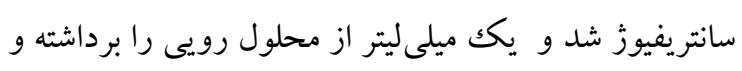

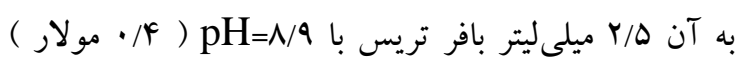

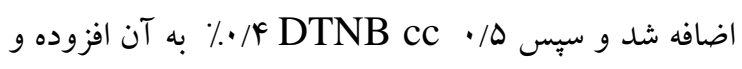
ها دقيقه انكوبه تا واكنش كامل شود، لوله را بهخوبى هم

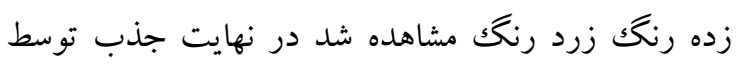

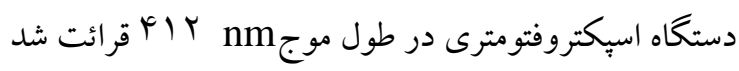

\section{تست MTT}

يكك ميلى ليتر از مخلوط ميتو كندرى هاى ايزوله شده از بافت

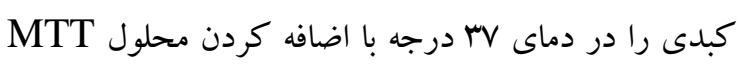

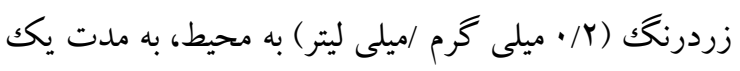

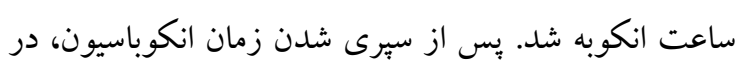
g V...

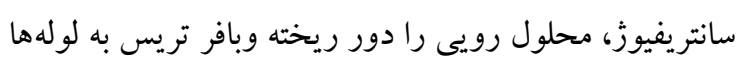

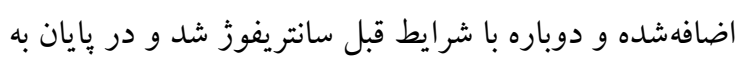




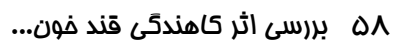

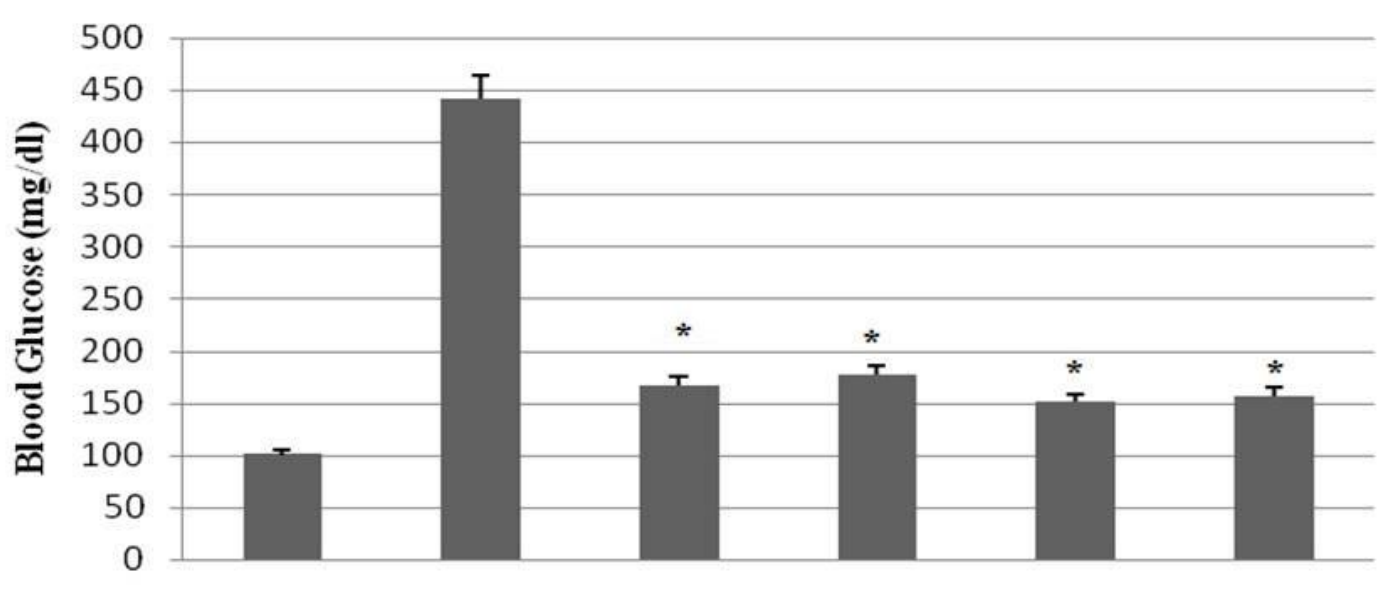

Negative STZ Metformin $50 \mathrm{mg} / \mathrm{kg} \quad 100 \mathrm{mg} / \mathrm{kg} \quad 200 \mathrm{mg} / \mathrm{kg}$ Control

\section{Animal Groups}

$$
\begin{aligned}
& \text { نمودار ا: ميزان قند خون در موشهاى تيمار شده با استريتوزوسين و عصاره هيدروالكلى (P> ) }
\end{aligned}
$$

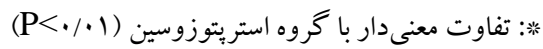

تأثير گياه سرو بر روى تغيير وزن در موشهاى نرمال و ديابتى شده:

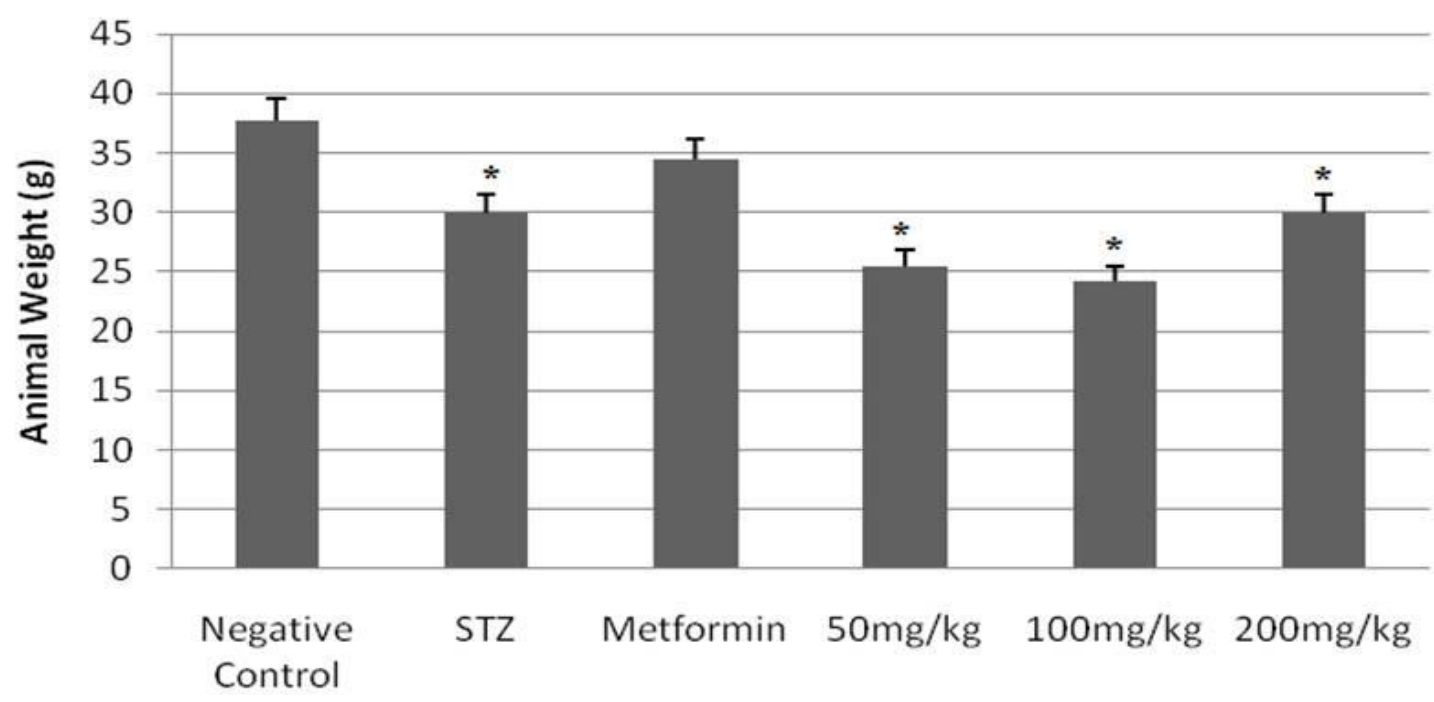

\section{Animal Groups}

نمودار r: ميزان تغيير وزن در موشهاى تيمار شده با استريتوزوسين (ديابتى) و عصاره

)

موشهاى دريافت كننده عصاره تغيير وزن معنىدارى در مقايسه با STZ مشاهده نشد ه •/P> درحالى كه متفورمين

$$
\begin{aligned}
& \text { همانطورى كه در نمودار ب نشان داده مىشود كروه } \\
& \text { دريافت كننده نرمال سالين نسبت به كروه دريافت كننده } \\
& \text { استريتوزوسين داراى وزن بيشتى است }
\end{aligned}
$$




$$
\begin{aligned}
& \text { اثر محافظتى گياه سرو زربين بر ميزان اكسيداتيو استرس در } \\
& \text { نسبت به استريتوزوسين باعث تغيير معنىدار در وزن گرديده } \\
& \text { موش هاى نرمال و ديابتى شده: }
\end{aligned}
$$

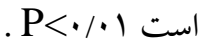

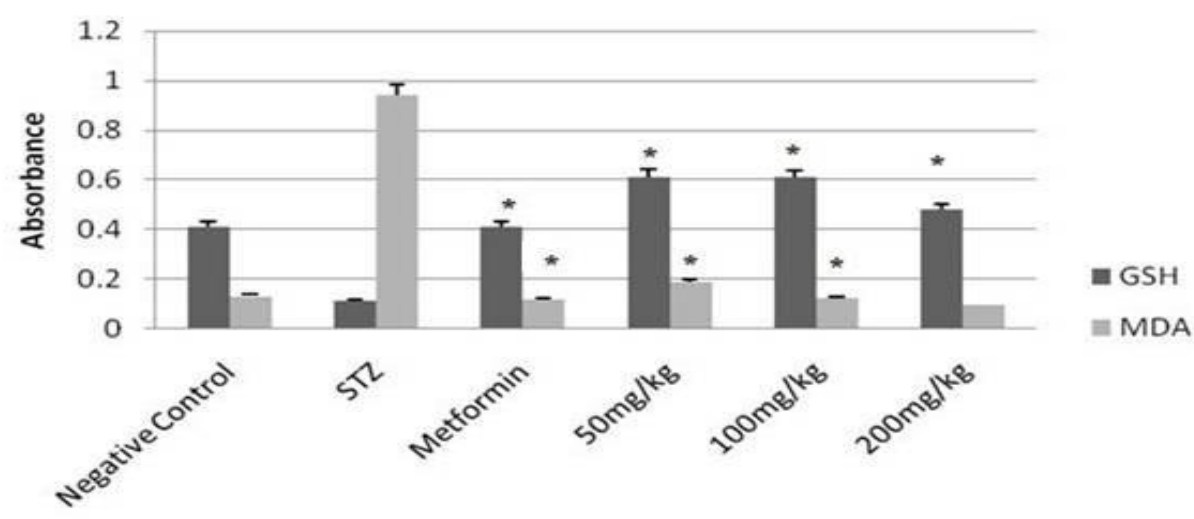

Animal Groups

نمودار ب: ميزان كلو تاتيون و مالونيل دى آلدئيد در بافت كبدى موشهاى تيمار شده با استريتوزوسين (ديابتى) و عصاره

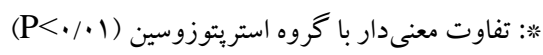

نمودار F- درصد viability ميتو كندرى كبد در موشهاى تيمار شده با استريتوزوسين (ديابتى) و عصاره استريتوزوسين

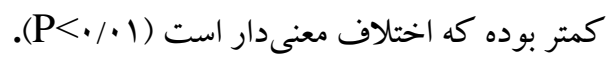

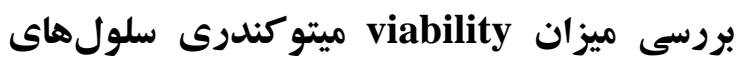
كبدى در موشهاى نرمال و ديابتى شده

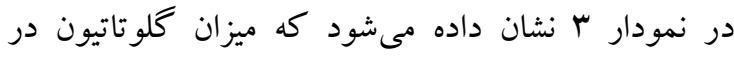

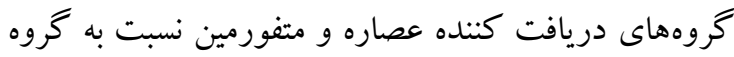

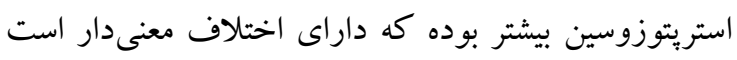

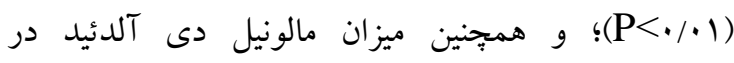
كروههاى دريافت كننده عصاره و متفورمين نسبت به گروهين 


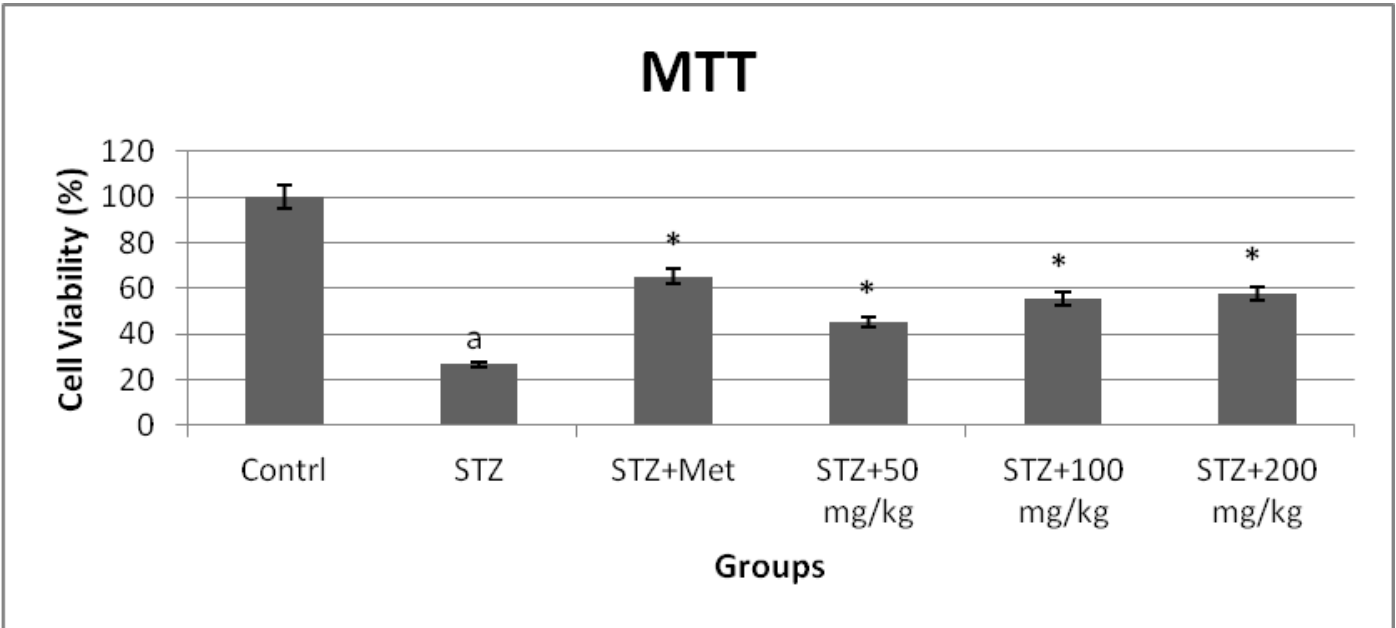

مطالعات بالينى اخير مشخص كرده كه هيير گليسمى علت مهم بيشرفت و توسعه اختلال عملكرد مغز در افراد ديابتى است از طرفى در افراد ديابتى استرس اكسيداتيو يكك نقش ونش

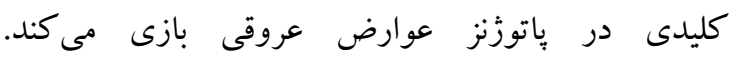
راديكالهاى آزاد نقش مهمى هم در سلامتى و هم در درى

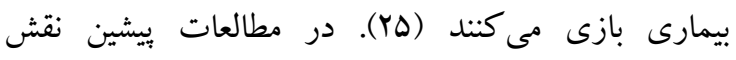

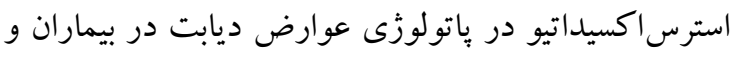

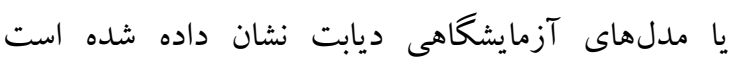

(YFG YQ )

در مطالعهى ما نيز افزايش ليييد براكسيداسيون در موشهاى

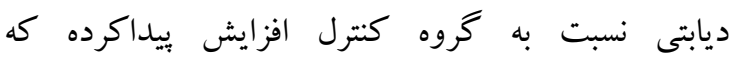

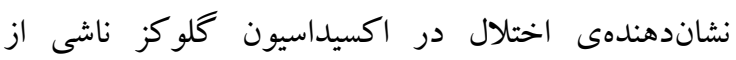

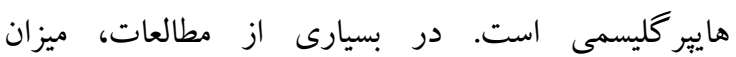
ليييديراكسيداسيون ناشى از ديابت ارزيابى شده است. در

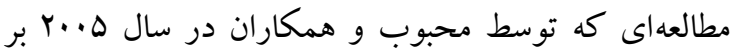
روى سطوح سرمى ليييدير اكسيداسيون (مالونيل دى آلدئيد) و آنزيم آنتىاكسيدانمى در بيماران ديابت يكك زن و مرد در لرد هند انجام گرفت، نتايج حاكى از افزايش غلظت دائ ماركر لييدير اكسيداسيون (مالونيل دى آلدئيد) و كاهش كلوتاتيون سرم در هر دو گروه زن و مرد بيماران تيب دو ديابت در مقايسه با گروه غيرديابت يك بود و نتيجه كيرى آنها اين بود كه تغيير در اين دو فاكتور ممكن است خيلى زودتر از شروع عوارض ثانويهى ديابت نوع دو اتفاق بيفتد (Y)).
نمودار F: درصد viability ميتو كندرى سلولهاى كبدى در گروههاى دريافت كننده عصاره و متفورمين با گروه استريتوزوسين

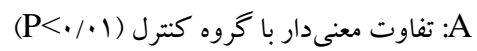

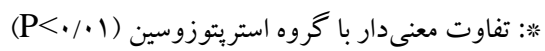

همانطورى كه در نمودار f نشان داده مىشود درصد ميتو كندرى سلولهاى كبدى در گروههاى viability دريافت كننده عصاره و متفورمين با كروه استريتوزوسين داراى اختلاف معنىدار است (P</1) و و درصد ميتو كندرى كبدى در گروههاى دريافت كننده

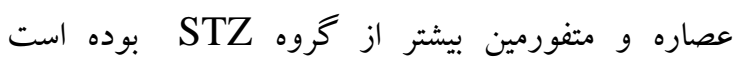
$(\mathrm{P}<\cdot / \cdot 1)$

ديابت يكك بيمارى متابوليكك بوده كه با افزايش اكسيداتيو

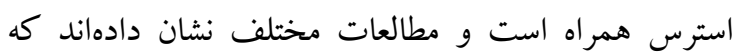
هايير كلايسمى در افراد ديابتى باعث افز ايش توليد كونه أهاى

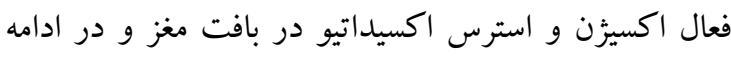

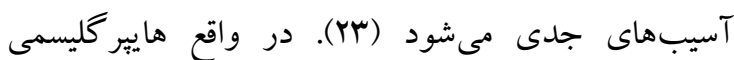
ديابتى علت اصلى عوارض ديابت است كه با افزايش اتواكسيداسيون كلو كز و راديكالهاى آزاد منجر به استرس اكسيداتيو مىشود (YY)؛ و بنابراين مصرف آنتى اكسيدانتها مى تواند در كاهش عوارض ديابت نقش داشته باشد.

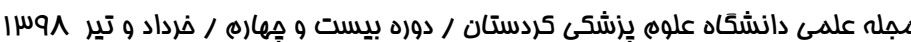


درصد و فعاليت ضد ويروسى در برابر ويروس هربس

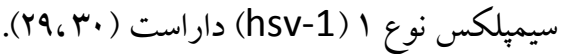

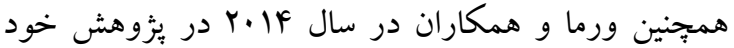

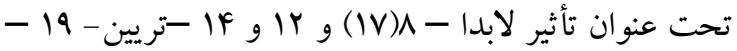
اوييكك اسيد ميوه سرو در سركوب هيبربلازى خوشخيم يروستات در موش و مدلهاى انسانى از طريق مهار آندروزن و سيخنالينگ stat3 به اين نتيجه رسيدند كه عصاره ميوه سرو باعث مهار تكثير سلولهاى - استراز و سركوب عمل آندروزن در يروستات مىشود ( آr). اصغرى و همكاران در سال r Y Y در بيزوهش خود تحت عنوان تجزيهوتحليل شيميايى و فعاليتهاى بيولوزيكى و آنتى باكتريال سرو زربين به اين نتيجه رسيدند كه عصاره سرو علاوه بر خواص آنتى باكتريال داراى خواص آنتى اكسيدانت و ضد كلوكوزيله شدن نيز است و در بيشخيرى از عوارض ديابت و عوارض قلبى - عروقى مؤثر است

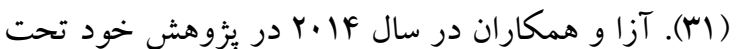
عنوان اثرات آنتى اكسيدانت، ضد التهاب و ضد بروليفراتيو روغن هاى حياتى به اين نتيجه رسيدند كه روغنهاى حياتى (بهارنارنج، ليمون، سرو، اكاييتوس، رازيانه و آويشن داراى خواص ضد ميكروبى، ضد التهاب، دافع حشرات، ضد سرطان و آنتىاكسيدانى هستند و راديكالهاى آزاد را مهار مى كنند (Yr). افشارزاده و همكاران در سال ساיץr در In يثزوهش خود تحت عنوان فعاليتهاى ضدميكروبى Vitro به اين نتيجه رسيدند كه برگك و ميوه مخروطيان از جمله عصاره سرو داراى فعاليت ضدميكروبى در برابر يسودوموناس آئروزينوزا، استافيلوكوكوس اورئوس، اشريشيا كولى و كانديدا آلبيكانس هستند (سM). اسسبوساتو

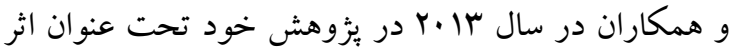
بالينى سرو و ارس به اين نتيجه رسيدند كه عصاره سرو سبب كاهش علائم تنفسى آلرزيك از جمله رينيت، التهاب ملتحمه و آسم مى شود (MF).
يكى از راههاى مؤثر و اقتصادى براى كنترل بهتر عوارض ناشى از هايبر گلايسمى، استفاده از آنتى اكسيدانت هاى كياهى يا سنتيم است كه بىخطر بوده و بهراحتى توسط سيستم سلولى يذيرفته مىشوند. مطالعات زيادى نشاندهندهى ميزان لييد براكسيداسيون و كلوتاتيون در موشهاى ديابتى دستخوش تغيير مىشود و تنظيم اين مار كرها توسط آنتى اكسيدانت هاى طبيعى مقدور است. در مطالعهاى اثر pelargonidin به عنوان يك تركيب آنتى اكسيدانت در درمان درد نوروياتيك در رت هاى ديابتى شده با استريتوزوسين بررسى شد كه pelargonidin باعث كاهش درد در تست فرمالين و صفحه داغ شده و همجنين باعث كاهش لييديراكسيداسيون و افزايش سطح آنزيم هاى آنتى اكسيدانت در مغز رت هاى ديابتى شد و بهاينترتيب pelargonidin با كاهش استرس اكسيداتيو، درد نوروياتيكك را كاهش داد (YV). همجنين در مطالعهاى كه در سال ها··r توسط Yiz و همكارانش انجام شد اثر محافظتى عصاره اتانولى قارج هريسيوم در نوروياتى رت هاى ديابتى شده با آلو كسان مورد بررسى قرار گرفت. در اين آزمايش درمان با هريسيوم آستانه درد را افزايش داده و كاهش قابلملاحظهاى در كلو كز پِلاسما و ادرار ايجاد كرد. در اين آزمايش، افزايش در لاكتات دهيدروزناز (LDH)، لييديراكسيداسيون، كاهش فعاليت كلو تاتيون ير اكسيداز و كلو تاتيون ردو كتاز و ديخر فاكتورهاى استرس اكسيداتيو در نتيجه ديابتى شدن ايجاد شده بود كه با دريافت قارج هريسيوم ظرفيت آنتى اكسيدانتى تام (TAOS)، به صورت قابل ملاحظهاى نسبت

$$
\text { به كروه ديابتى كاهش داشت (YN). }
$$

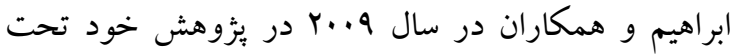
عنوان تركيبات و فعاليت بيولوزيكى عصاره كلروفرم و سرو به اين نتيجه رسيدند كه اسانس برگك سرو داراى فعاليت ضد ميكروبى در برابر باسيلوس با حداقل غلظت مهارى VD 


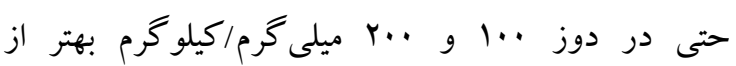
متفورمين عمل كرده است.

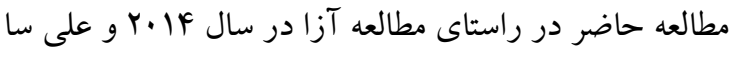

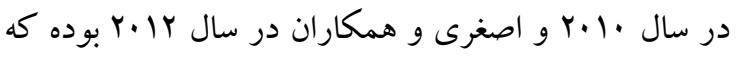

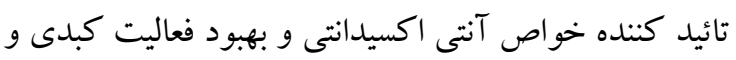

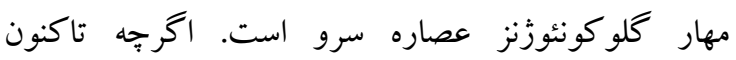
مطالعات در خصوص فعاليت ضد ديابتى گياه سرو بسيار

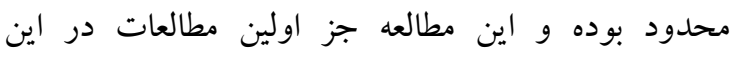

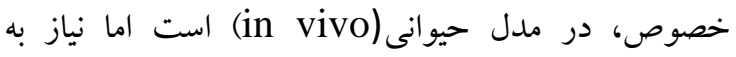
بررسىهاى تكميلىتر بخصوص بررسى فاكتورهاى ديخر

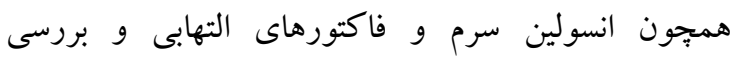

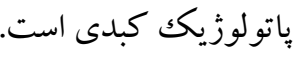

\section{نتيجه كيرى}

بهوروكلى نتايج حاصل از سنجش مارئ ماركرهاى آسيب اكسيداتيو نشاندهندهى افزايش ميزان استرس اكسيداتيو در كبد موشهاى ديابتى بوده كه با درمان تركيبى سرو و و متفورمين به مدت F هفته كاهش استرس اكسيداتيو ناشى از ديابت مشاهده شد. درمجموع با توجه به اثرات مناسب سرو مرون در كاهش قند خون و استرس اكسيداتيو در بررسىها و و بهابه

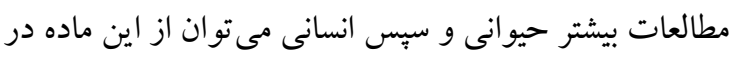

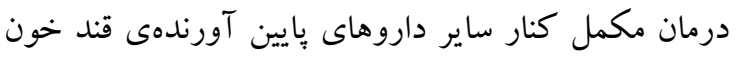
براى كنترل هر جهه بهتر عوارض ديابت استفاده كرد.

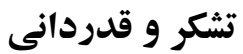

اين تحقيق در غالب طرح تحقيقاتى و باياننامه دانشجويى

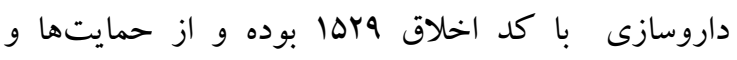
يشتيبانى هاى مادى و معنوى معاونت تحقيقات و فن آورى و و داري

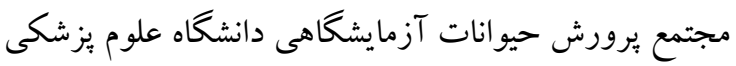
مازندران به دليل در اختيار قرار دادن آزمايشگاه و اتاق
على سا و همكاران در سال •r.l. در بزوهش خود تحت عنوان نقش محافظتى ارس و سرو در برابر تتراكلريد كربن به اين نتيجه رسيدند كه عصاره ارس و سرو بس از تزريق يكك عامل مانند استرس اكسيداتيو مانند تتراكلريدكربن اثر وسئن قابل توجهى در افزايش عملكرد كبد و كليه داشته و ممكن مان است داراى يتانسيل درمانى در سميت كبد و وركليه باشند

مدتها درخت سرو يكك گياه داروئى در نظر گرفنه

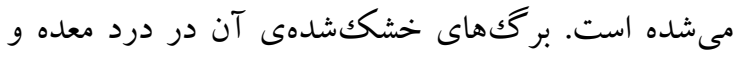
همجنين درمان ديابت، ميوههاى آن در درمان التهاب، درد

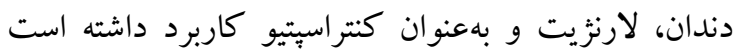

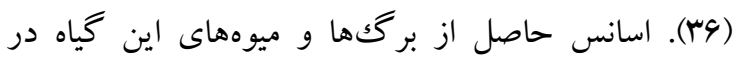

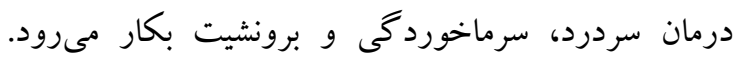
بهواسطهى اثرات خوب فارماكولوزيكك و دارويى اين گياه، سرو بهطور گسترده در تركيبات آرايشى، عطرها و صابون بكار مىرود (rV). مقالات متعددى در خصوص تر كيبات

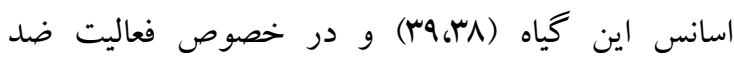

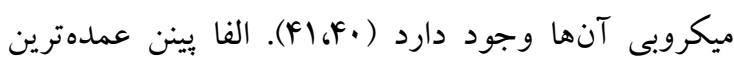

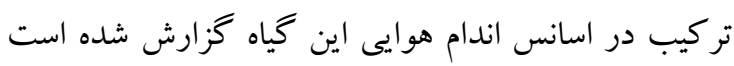

در مطالعه حاضر اثرات عصاره هيدرالكلى اين گياه را در كاهش قند خون و شدت استرس اكسيداتيو در كنار متفورمين داروى متداول مورد استفاده در درمان ديابت

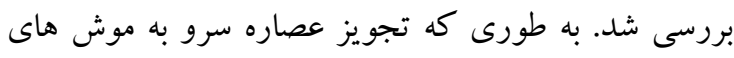

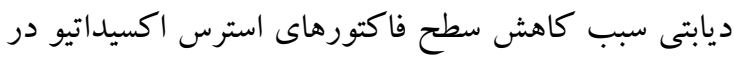

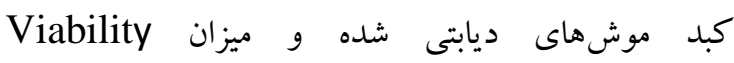
ميتو كندريايى كبدى بهبود يافت. اكرجهه عصاره سرو باعث كاهش قند خون در سه دوز استفاده كرديده شد اما در وزن كئن

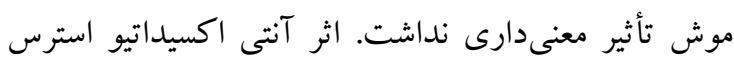
عصاره سرو در بافت كبدى قابل مقايسه با متفورمين بوده و 


$$
\text { تشريح و جناب آقاى دكتر سروى مديريت مجتمع حيوانات تشدير و تشكر مرد. }
$$

\section{References}

1. Wild S, Roglic G, Green A, Sicree R, King H. Global prevalence of diabetes: estimates for the year 2000 and projections for 2030. Diabetes Care 2004;27:1047-53,

2. Agashe S, Petak S. Cardiac Autonomic Neuropathy in Diabetes Mellitus. Methodist Debakey Cardiovasc J 2018;4:251-6.

3. Van Dam PS. Oxidative stress and diabetic neuropathy: pathophysiological mechanisms and treatment perspectives. Diabetes Metab Res Rev 2002;18:176-84.

4. Vincent AM, Russell JW, Low P, Feldman EL. Oxidative stress in the pathogenesis of diabetic neuropathy. Endocr Rev 2004;25:612-28

5. Teodoro JS, Nunes S, Rolo AP, Reis F, Palmeira CM. Therapeutic options targeting oxidative stress, mitochondrial dysfunction and inflammation to hinder the progression of vascular complications of diabetes. Front Physiol 2019;17:1857-900.

6. Maraschin JF. Classification of diabetes. Adv Exp Med Biol 2012;771:12-9.

7. Melanitou E, Fain P, Eisenbarth G S. Genetics of type 1A (immune mediated) diabetes. J Autoimmun 2003;21:93-5.

8. Mandrup-Poulsen T, Pickersgill L, Donath MY. Blockade of interleukin 1 in type 1 diabetes mellitus. Nat Rev Endocrinol 2010;6:158-60.

9. Mehri A, Hasani-Ranjbar S, Larijani B, Abdollahi M, A Systematic review of efficacy and safety of urtica dioica in the treatment of diabetes. Int J Pharmacol 2011;7:161-70.

10. Selim SA, Adam ME, Hassan Sh M. Albalawi AR. Chemical composition, antimicrobial and antibiofilm activity of the essential oil and methanol extract of the Mediterranean cypress (Cupressus sempervirens L.). BMC Complement Altern Med 2014; 14:179.

11. American Diabetes Association. Diabetes Care 2010; 33: S62-S69.

12. Lee AJ, Hiscock RJ, Wein P, Walker SP, Permezel M. Gestational diabetes mellitus: clinical predictors and long- term risk of developing type 2 diabetes a retrospective cohort study using survival analysis. Diabetes Care 2007; 30:878-85.

13. Metzger B E, Buchanan TA, Coustan DR, De Leiva A, Dunger DB, Hadden DR, et al. Summary and recommendations of the fifth international workshop-conference on gestational diabetes mellitus.Diabetes Care 2007;30:251-5.

14. American Diabetes Association, Gestational diabetes mellitus. Diabetes Care 2004;27:8893.

15. Henzen C. Monogenic diabetes mellitus due to defects in insulin secretion. Swiss Med Wkly 2012;142:w13690.

15. Sposato B, Scalese M. Prevalence and real clinical impact of Cupressus sempervirens and Juniperus communis sensitisations in Tuscan "Maremma", Italy. Allergol Immunopathol (Madr) 2013;41:17-22.

16. Marionj F. Evidence-based nutrition principles and recommendations for the treatment and prevention of diabetes and related complications. Diabetes Care 2002;25:148-95.

17. Maraschin JF. Classification of diabetes. Adv Exp Med Biol 2012;771:12-19.

18. Yamamoto K, Tsuji Y, Aso Y, Hamasaki T, Shirahata S, Katakura Y. Effect of diazinon exposure on antioxidant reactions in the silkmoth, Bombyx mori. J Appl Entomol 2011; 135:320-5. 
19. Hosseinzadeh H, Sadati N. The Protective Effect of Allium sativum L. Clove aqueous and methanolic extracts against hypoxia-inducedlethality in mice. Phytother Res 2003;17:279 -81. 20. Shimada K, Fujikawa K, Yahara K, Nakamura T. Antioxidative properties of xanthin on autoxidation of soybean oil in cyclodextrin emulsion. J Agric Food Chem 1992; 40: 945-48 21. Shaki F, Hosseini MJ, Ghazi-Khansari M, Pourahmad J. Toxicity of depleted uranium on isolated rat kidney mitochondria. Biochim Biophys Acta 2012;1820:1940-50.

22. Sadegh C, Schreck RP. The Spectroscopic determination of aqueous sulfite using ellman's reagent. MURJ 2003;8:39-43

23. Yamamoto K, Tsuji Y, Aso Y, Hamasaki T, Shirahata S, Katakura Y. Effect of diazinon exposure on antioxidant reactions in the silkmoth, Bombyx mori. J Appl Entomol 2011;135:320-5.

24. Naito Y, Uchiyama K, Aoi W, Hasegawa G, Nakamura N, Yoshida N. Prevention of diabetic nephropathy by treatment with astaxanthin in diabetic $\mathrm{db} / \mathrm{db}$ mice. Bio Factors 2004;20:49-59.

25.Ardakani A,Mohammadi M. Diabetes, oxidative stress and anti-oxidant. JSSU 2009;17:197-214. [In Persian]

26. Mahboob M, Rahman MF, Grover P. Serum lipid peroxidation and antioxidant enzyme levels in male and female diabetic patients. Singapore Med J 2005;46:322-24.

27. Mirshekar M, Roghani M, Khalili M, Tourandokht, Baluchnejadmojarad, Moazzen SA. Chronic oral pelargonidin alleviates streptozotocin-induced diabetic neuropathic hyperalgesia in rat: involvement of oxidative stress. Iranian Biomed J 2010;14:33-9.

28. Yi Z, Shao-Long Y, Ai-Hong W, Zhi-Chun S, Ya-Fen Z, Ye-Ting X, et al. Protective effect of ethanol extracts of hericium erinaceus on alloxan-induced diabetic neuropathic pain in rats. Evid Based Complement Alternat Med 2015;2015:595480.

29. Nouri AB, Dhifi W, Bellili S, Ghazghazi H, Aouadhi C, Chérif A, et al. chemical composition, antioxidant potential, and antibacterial activity of essential oil cones of tunisian cupressus sempervirens. J Chem 2015; 2015:1- 8.

30. Ibrahim NA, El-Seedi HR, Mohammed MM. Phytochemical investigation and hepatoprotective activity of Cupressus sempervirens L. leaves growing in Egypt. Nat Prod Res 2007;21:857-66.

31. Verma V, Sharma V, Singh V, Kumar R, Khan MF, Singh AK, et al. Labda-8(17),12,14trien-19-oic acid contained in fruits of Cupressus sempervirens suppresses benign prostatic hyperplasia in rat and in vitro human models through inhibition of androgen and STAT-3 signaling. Phytother Res 2014;28:1196-203.

32. Aazza S, Lyoussi B, Megías C, Cortés-Giraldo I, Vioque J, Figueiredo AC, et al. Antioxidant, anti-inflammatory and anti-proliferative activities of Moroccan commercial essential oils, Nat Prod Commun 2014;9:587-94.

33. Afsharzadeh M, Naderinasab M, Tayarani Najaran Z, Barzin M, Emami SA. In-vitro antimicrobial activities of some iranian conifers. Iran J Pharm Res 2013;12:63-74.

34. Russell JW, Zilliox LA. Diabetic neuropathies. Diabetes Care 2005;28:956-62.

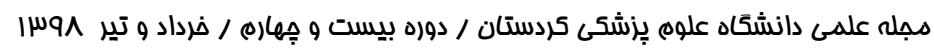


35. Ali SA, Rizk MZ, Ibrahim NA, Abdallah MS, Sharara HM, Moustafa MM. Protective role of Juniperus phoeniceaand Cupressus, sempervirensagainst CCl4 Magda Mohamed Moustafa. World J Gastrointest Pharmacol Ther 2010;1:123-31.

36. Mascolo N, Autore G, Capasso F, Menghini A, Fasulo MP. Biological screening of Italian medicinal plants for anti-inflammatory activity. Phytother Res 1987;1:28-31.

37. Usher GA: Dictionary of plants used by Man. London: Constable and Company; 1974.

38. Chanegriha N, Baâliouamer A, Meklati BY, Favre-Bonvin J, Alamercery S: Chemical composition of Algerian cypress essential oil. J Essent Oil Res 1993;5:671-4.

39. Tapondjou AL, Adler C, Fontem DA, Bouda H, Reichmuthm C. Bioactivities of cymol and essential oils of Cupressus sempervirens and Eucalyptus saligna against Sitophilus zeamais Motschulsky and Tribolium confusum du Val. J Stored Prod Res 2005;41:91-102.

40. Mazari K, Bendimerad N, Bekhechi C, Fernandez X. Chemical composition and antimicrobial activity of essential oils isolated from Algerian Juniperus phoenicea L. and Cupressus sempervirens L. J Med Plants Res 2010;4:959-64.

41. Boukhris M, Regane G, Yangui T, Sayadi S, Bouaziz M. Chemical composition and biological potential of essential oil from Tunisian Cupressus sempervirens L. J Arid Land Stud 2013;22-1:329-32. 